ьвівський н ціон льний університет імені в н вул. . орошенк , 41, м. ввів, 79000, кр їн

икон но н ліз т порівняння морфології к м'яних розсипів ивулянського і овбуш нського хребтів кибових орг нів. озглянуто морфометричні х р ктеристики, мех нізм утворення, вік т суч сний ст н розсипів щодо їхнього поширення н схил х. роблено висновки про п леогеогр фічні умови їхнього утворення.

лючові слов : к м'яні розсипи, схил, обк т ність, орг ни, орієнт ція ул мків.

ірський м сив орг ни вв ж ють одним 3 м ловивчених регіонів кр їнських

рп т через в жкодоступність. пеці льних пр ць з вивчення к м'яних розсипів поки що нем є. літер турних джерел х укр їнських т польських учених можн зн йти лише уривч сті д ні про можливе їх походження. орфометричні особливості к м'яних розсипів орг нів пр ктично не вивчені. е досі вчені не дійшли спільного висновку, щодо термінології к м'яних розсипів т їхньої ідентифік ції.

європейській літер турі к м'яні розсипи ч стіше н зив ють к м'яними полями, бо к м'яними морями ( нгл. - bock field, stone field ).

словником . йлі т мп “block field” озн ч є: 1) згром дження к м'яних ул мків н б г тьох високих гірських вершин х і н субполярних остров х, які $є$ н слідком руйнув ння гірських порід у процесі інтенсивного морозного звітрюв ння. ух ючись униз по схилу, вони перетворюються в stone rivers (к м’яні ріки бо куруми); 2) вирівняні ділянки н зн чніших височин х у середніх і високих широт х, які ч сто покриті розсип ми гострих к м'янистих ул мків, які н зив ють block fields (к м'яне поле), boulder fields (в лунне поле); н логічні німецькі терміни: Felsenmeer, Blockmeer, Blockfelder. о скл дені винятково з місцевих порід ці к м'яні ул мки утворюються вн слідок морозного звітрюв ння, можуть утворюв ти н вершині гори товщу потужністю в декільк метрів.

німецькій літер турі н йч стіше вжив ють термін Blockmeer, відобр ж ючи положення н схилі т мех нізм переміщення ул мків (конжелюфлюкційний мех нізм). еякі втори припуск ють можливість іншого мех нізму тр нспортув ння терміном Blockstrom окреслюють ізольов ні смуги ул мків бо скельні ул мки, переміщені льодовиком [8].

польській літер турі н йч стіше вжив ють термін rumowiska skalne. . озинський т кож їх н зив в rozwaliskami skalnymi, одн к цей термін не прижився. роте в суч сній польській літер турі для озн чення к м'яних розсипищ ч сто з стосовують термін goloborzy, що в дослівному перекл ді укр їнською озн ч є “голий бір” [11,

(C) еселов ., 2012 
c. 47-48]. одноч с спр ведливо . лятк з зн ч є, що цей термін можн вжив ти тільки для силових к м'яних розсипів, які розвив ються серед лісу [10].

м'яні розсипи н йліпше досліджені в гор х ибіру т лекого ходу, де їх н зив ють курум ми. вньотюрське слово “курум” озн ч є “б р няче ст до” - скупчення к міння, схожого з зовнішнім виглядом н ст до б р нів [1, с. 4].

прикл д, місцеві жителі н вколишніх сіл орг нів н зив ють їх “горг н ми” бо ж “грегот ми”, пояснюючи це тим, що вони під ч с п діння вид ють специфічні звуки, що н г дує грегіт; є й сел , де н зив ють к м'яні розсипи “цокот ми”, к жучи, що вони цокотять, ще інші - “сенети”. скільки універс льного визн чення нем є, то вв ж ємо, що не доцільно використовув ти місцеві н зви, доки вони н уково не обгрунтов ні, н томість н д лі вжив ти термін “к м’яні розсипи”, як це роблять дослідники . чук, . удько т . ливк $[2,3,5,6]$.

м'яні розсипи - це скупчення н схил х грубоул мкового м тері лу, що з йм ють м йд н нерідко в декільк кв др тних кілометрів, формуються в умов х морозного клім ту (нів льного бо перигляці льного) [4, с. 108]. м йбутньому м ємо н меті обгрунтув ти місцеві н зви розсипів у орг н х, розробивши дет льну їхню кл сифік цію.

тже, к м'яні розсипи н леж ть до поширених і н йменш вивчених явищ.

крім суперечностей щодо термінології, суттєво відрізняється підхід різних н укових шкіл стосовно вивчення к м'яних розсипів. дні вчені роблять кцент н генезу розсипів, інші ж пит ння генези не з чіп ють, велику ув гу приділяють їхньому поширенню т дин міці. и спробув ли об'єдн ти ці дв підходи. ід ч с досліджень з стосов но метод 'є (Cailleux, 1947), с ме-з міри кут н хилу схилу, з лежність виступу к м'яних розсипів від кут н хилу схилу; орієнт ція довгої осі брил, якими скл дені розсипи, і кут їхнього н хилу у співвідношенні до н пряму схилу; розподіл розміру брил н вир зні к тегорії, змінність структури з лежно від висоти положення к м'яних розсипів, експозиції і н хилу схилу, т кож літології т тектоніки лож к м'яних розсипів, обк т ність, зіст влення кількісних пок зників у відсотк х брил, які спрямов ні $з$ п дінням схилу (кут між зимутом довгої осі т п дінням схилу ст новить менше $45^{\circ}$ ), т брил, які спрямов ні впоперек схилу (кут між зимутом довгої осі і н хилом схилу ст новить більше $45^{\circ}$ ), визн чення зв'язку між кутом н хилу осі брил до н хилу схилу (у відсотк х кількості тих брил що “з нурюються” (н хил брил більший, ніж н хил схилу) т тих що “вирин ють” (менший н хил брил, ніж н хил схилу), зв'язок розсипів з м теринською породою [10, с. 70].

г лом з міряно 1600 ул мків, по 100 н кожній з 16 досліджув них ділянок, 8 точок було з кл дено н овбуш нському хребті, т $8-$ н ивулянському, отрим ні д ні є обчисленими т ст новлять основу для вивчення перелічених вище х р ктеристик.

йбільшого поширення к м'яні розсипи н були у середньогірних геоморфологічних підр йон х колівської т $\mathrm{p}$ шківської морфоструктур другого порядку кибових орг нів, особливо овбуш нській і ивулянській морфоструктур х третього порядку.

орг нський тип літоморфоструктури - це повні т зріз ні вузькі нтиклін лі з чергув нням ритмічних ш рів пісковикового і глинистого флішу, яким відповід ють ізольов ні ізоклін льні м сиви, глибоко розчленов ні вузькими V-подібними долин ми.

кий тип літоморфоструктур є сприятливим для процесів кріпу корінних порід - основного чинник підвищеної тріщинув тості пісковикових ш рів [2]. 
меж х кибових орг нів н йбільше скупчення з умовно н йбільшою генетичною різном нітністю к м'яних розсипів є н лінії ивулянського і овбуш нського хребтів, що входять до р шківської морфоструктури, де к м'яні розсипи з йм ють $100 \%$ поверхонь вершин, $75 \%$ гребенів і $75 \%$ схилів. орфоструктур відрізняється від інших гірських хребтів орг нів різкістю форм, м сивністю т великими розмір ми полів к м'яних розсипів т їхньою потужністю. я ч стин м сиву $є$ н йвищою ч стиною кибових орг нів, і орогр фічно утворює одну лінію гір, яку можн н зв ти орогр фічною віссю кибових орг нів. овбуш нський хребет з його вершиною г. овбуш нк 1754,6 м т г. едмежик 1736 м, ивулянський хребет з вершин ми л ивуля 1818 м, елик ивуля 1836 м [3]. ме тому для досліджень обр но цю ділянку дослідження.

хили ивулянського хребт сильно розчленов ні глибоко вріз ними численними поток ми й утворюють велику низку відрогів. м'яні розсипи скл дені тут великими брил ми ямненських пісковиків, які покрив ють пр ктично весь хребет, криволісся м $є$ порівняно невеликі ділянки н схил х хребт .

сі схили гір у зоні виходу ямненських пісковиків н поверхню покриті к м'яними розсип ми, як і прилеглі ділянки лісу. сюди к м'яні блоки є рухомими. е стосується не лише відкритих безлісих ділянок, й ділянок, покритих тр вою, ч г рник ми, лісом.

більшості н всіх розсип х утворюються н рости лиш йників пр ктично по всій площі, що з свідчує невисоку ктивність ул мків.

ивулянський хребет для дослідження розділено н північно-східну т південно3 хідні зони. івнічно-східн ч стин стрімк 3 крутістю схилу $45^{\circ}$ т більше, вкрит криволіссям до висоти 1700 м, т подекуди сяг є пр ктично вершини 1820 м. івденно-з хідні схили - вологіші з крутістю до $25^{\circ}$ і межею криволісся до 1500 м т великими полями к м'яних розсипів. м'яні розсипи перелічених зон розгляд ють як ділянки з н гром дженого скельного м тері лу, що д є певну з кономірність в їхньому розт шув нні, як $з$ лежить від кут н хилу поверхні схилу, генетичного х р ктеру i віку цих ділянок. стрімких схил х 3 крутістю $45^{\circ} \mathrm{T}$ більше блоки розміщені у вигляді п сів і к м'яних язиків, що ч сто об'єднуються й утворюють комп ктні обл сті, ця ч стин схилу м є ввігнутий профіль, що свідчить про ст рший вік цього схилу. південно-з хідних схил х більш вирівняних пологіших ділянок, розсипи м ють форму п сів, які об'єднуючись між собою, утворюють к м'яні поля, “порозрив ні” смуг ми криволісся сосни льпійської. ут форм брилових н гром джень ускл днен н явністю х р ктерних сходин, які переміщ ються під впливом гр віт ції з допомогою л вин т гр віт ційних зміщень. хній рух ч стково г льмують 3 рості жерепу і верхівки великих в лунів, що й призводить до утворення сходин. рили перев жно скл дені свіжими продукт ми звітрюв ння з гострокутними ул мк ми потужністю до 1,5 м. т рший покрив розт шов ний у нижній ч стині схилу у вигляді осередків і смуг.

евну роль у розт шув нні розсипів відігр л діяльність людини. е простежується н привершинних ділянк х, де під ч с двох світових воїн були окопи і бункери, укріплені брил ми. ч сом вони зруйнув лись, і сьогодні відслонені лише стінки природних брилових н ш рув нь.

озсипи південно-з хідного схилу м ють випуклий поперечний профіль і симетричну будову, випуклість свідчить про порівняно нед внє переміщення скельного м тері лу. лоскі блоки, що є в скл ді язик , розміщені подібно до черепиці - одні н одному. рубші ул мки містяться н горі язик, що свідчить про їхню молодість. т р- 
ші розсипи, що покрив ють стрімкі північно-східні схили ивулянського хребт , м ють зворотний порядок розміщення ул мкового м тері лу з огляду н розмір.

гідно з текстурою м теринської породи, у розсип х перев ж ють (близько 90 \%) плоскі блоки зі співвідношенням товщини до довжини і ширини 1:6 і 1:4. йгрубші фр кції 2,0 0,5 1,0 м є н вершині, н йдрібніші 0,20 $0,10 \quad 0,15$ м у сідловині.

фіксов но т кож зміну фр кцій у профілях стоку - н йбільші ул мки розміщені у привершинних ділянк х, н йдрібніші - у нижніх ділянк х схилу. йбільших розмірів сяг ють плити, що розт шов ні н схил х північної окр їни ивулянського хребт . овсім ін кше вигляд ють конуси винесення під північно-східними схил ми, де у верхній ділянці перев ж ють фр кції 1,5 $0,5 \quad 1,0$ м, внизу - 0,50 $1,0 \quad 0,60$ м. шості блоків м ють ті чи інші сліди обк т ності. івень поширення цього процесу д $€$ змогу створити умовний поділ н блоки з з гостреними кр ями, сл бко з гостреними і 3 округленими кр ями. локи з гострими кр ями перев ж ють у верхній ч стині конусів винесення (від 55-65 до 25-30 \% блоків з з округленими кр ями). нижніх ділянк х ця перев г вже незн чн і ст новить від 45-60 до 44-51\% блоків з з округленими кр ями.

м'яні розсипи н хребті овбуш нК поширені нерівномірно. г лом їх можн розділити 3 особливостями поширення н розсипи північно-східного т південно3 хідного схилів, як і в ивулянському хребті.

івнічно-східний схил - це крутий урвистий схил до 250-300 м з різкими форм ми рельєфу, його протяжність - близько 1000 м, н довжині м йже 500 м простежується м йже вертик льний уступ з ввишки 150 м. рутість схилу досяг є $35^{\circ}$, він сильно поріз ний видолинк ми, з сип ними ул мковим м тері лом. ижче по схил х вони дуже ч сто змінені ділянк ми обв льно-осипного зносу н копичення, що робить їх селенебезпечними. м'яні розсипи н північно-східному схилі хребт поширені від гребеня до висоти 1 250-1 350 м, зрідк до 1100 м [3, 6]. м’яні розсипи тут не ст новлять суцільного покриву вони ч сто є вже з дернов ними. . . т дницький пояснює це тим, що, н гром джуючись у величезній кількості, м си к м'яних брил, пересув лись униз по схилу під тиском вл сної в ги й тмосферних оп дів, покрив ли нижчі, пологіші ч стини схилів, в післяльодовиковий період північні схили орг нів отрим ли більше тмосферних оп дів, ніж південні, що спричинило їхнє інтенсивне з ліснення [7, c. 12].

ля південно-з хідного схилу х р ктерні порослі лиш йником невеликі з розмір ми брили без зв'язку з м теринською породою. озсип рухомий, чітко простежується діяльність різного роду звітрюв ння, особливо біологічного. рили м ють з округлені кути, звідси можн зробити висновок, що вони тр нспортув лись, ймовірно, з вершини.

скільки це підніжжя схилу, то можн вв ж ти, що це одні 3 н йст ріших к м'яних розсипів н схилі. ля схилу х р ктерні великі з розмір ми нестійкі плитч сті брили, м йже вирівняні. сто тр пляються к рнизи, це д є підст ву вв ж ти, що вони з трим лись у процесі тр нспортув ння. Здовж схилу можн виділити пригребеневу вирівняну ділянку, що є розколеною скелею пісковиків, де чітко простежується зв'язок брил з м теринською породою. ожливо, це структурний уступ. вершині гори брили тріщинув ті, розколюються. ут чітко простежується процес утворення ул мкового м тері лу. еликі брили (до 4 м) розколюються н менші 3 розміром ул мки н йрізном нітнішої форми, що х отично з ляг ють. езн чний відсоток брил покритий лиш йником, що свідчить про їхній ктивний розвиток, це не д є змоги з кріпитися н них прикипним лиш йник м. кож чітко виявлене гр віт ційне розколюв ння вершинних 
поверхонь, що відобр ж ється в морфології рельєфу. тже, можн простежити розвиток процесу розколюв ня броньов них пісковик ми вершинних поверхонь у р зі їхнього з г льного моноклін льного з ляг ння [9, с. 183]. г лом схил м йже повністю покритий к м'яними розсип ми. е спричинено його порівняно невеликою, місцями до

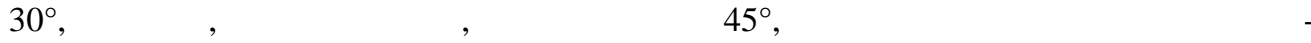
ну умов формув ння - чергув ння ст дій ктивного розвитку схилу т відносної його ст біліз ції. рутість схилу зменшується у н прямі від вершини до підніжжя, де він м є опуклу форму. еред к м'яних брил н гребеневій ділянці простежується жолобоподібне з глиблення, вершинн поверхня опущен і ніби з ходить у середину, що може бути н слідком розколюв ння вершинних поверхонь. кож у гребеневій ч стині хребт можн спостеріг ти монолітні пісковики у вигляді окремих скель т м йд нчиків, які поодиноко тр пляються в цьому жолобі. они н водять н думку, що ці п см утворилися вн слідок звітрюв ння чолової ч стини ямненських пісковиків, що виходять н поверхню, про це свідч ть, по-перше, н йбільше поширення к м'яних розсипів н пологих ділянк х схилу; по-друге, н явність криволісся н цих п см х; по-третє, ці п см є лише в з хідній ч стині південного схилу овбуш нки, де простяг ння пл стів орієнтов не $з$ північного з ходу н південний схід і співп д є з простяг нням хребт гори, п діння пл стів м є південно-з хідний н прям і збіг ється 35-55․ центр льній ч стині хребт пл сти простяг ються 3 ходу н схід, с м хребет м є південно-східну орієнт цію. відси виплив є, що вплив чолових ч стин пл стів н форми хребт і схилів поширюється тільки н його з хідну ч стину.

тже можн зробити висновок, що в морфології схилу чітко простежується геологічн зумовленість, як м є виріш льну роль у його формув нні т вигляді.

іст влення н ведених вище ф ктів д є підст ви стверджув ти, що розміщення к м'яних розсипів н досліджув ній території передусім зумовлене літологічними т клім тичними чинник ми. ід них з лежить решт чинників - рельєф, гідрологічні умови, рослинний покрив, що вз ємодіють у процесі утворення і дин міки к м'яних розсипів. мі хребти дуже схожі з морфоструктурою, орієнт цією схилів, поширенням розсипів, проте відрізняється морфологія с мих ул мків. овбуш нському хребті, н відміну від ивулянського, н прикл д, нем т ких фр кцій як 0,05 0,03 0,07 м, т 3 дернов ного схилу. томість розміри ул мків сяг ють 2,0 $1,0 \quad 3,0$ м, т кож є вихід м теринської породи у вигляді скелі ямненських пісковиків, що свідчить про молодший вік формув ння хребт .

озгляд ти кибові орг ни як цілісний об'єкт геоморфологічного н лізу д є змогу т к їхня х р ктерн рис, як м сове поширення к м'яних розсипів. тже, к м'яні розсипи орг нів - феномен льне явище для цієї гірської споруди рп т. еред к м'яних розсипів кибових орг нів вирізняються т кі літоформи, як к м'яні поля, смуги, язики, потоки тощо. кономірності їхнього поширення з леж ть від літоморфоструктурних особливостей. оловно к м'яні розсипи приурочені до виходів потужних пл стів ямненських і вигодських пісковиків, відрізняють 3 формою і морфологією т особливостями їхньої дин міки.

ет льними дослідженнями цих хребтів з'ясов но, що процеси кріпу к м'яних порід первинні у підготовці монолітних скель до фізичного і хімічного звітрюв ння. ізичне звітрюв ння виявляється у руйнув нні порід під ч с р птових змін темпер тури і зволоження, особливо у весняний період. імічне звітрюв ння ямненських пісковиків пов'яз не з н явністю у їхньому скл ді мікроскопічних мінер лів сидериту, що призводить до вилуговув ння поверхні порід і їхнього розтріскув ння [10]. тже, суч сне ут- 
ворення розсипів є результ том скл дних вз ємопов'яз них процесів гр вігенної підготовки порід т їхнього фізичного і хімічного звітрюв ння.

іст влення ф ктів д є підст ви стверджув ти, що розміщення К м'яних розсипів н досліджув ній території передусім зумовлене літологічними т клім тичними чинник ми. ід них з лежить решт чинників: рельєф, гідрологічні умови, рослинний покрив, що вз ємодіють у процесі утворення і дин міки розсипи.

'ясов но, що в епоху плейстоценових зледенінь процеси фізичного звітрюв ння відбув лися зн чно інтенсивніше, ніж у суч сному періоді, тому в орг н х є форми реліктових розсипів. кож інтенсивність розвитку розсипів 3 лежить від ктивності т ких суч сних геоморфологічних процесів, як нів ція, снігові л вини, суфозія, гр віт ційне зміщення схилового м тері лу. м’яні розсипи відповідно, вплив ють н виникнення зсувів і селів. сто верхів'я горг нських річок є селенебезпечними.

тже, з ур хув нням мех нізму утворення, віку і суч сного ст ну к м'яні розсипи орг нів можн об'єдн ти в чотири групи:

1) плейстоценові - д вньої перигляці льної зони;

2) плейстоценові т голоценові - у місцях гр віт ційного розсід ння вершинних поверхонь і відсід ння схилів;

3) голоценові - виникли вн слідок обв люв ння скелястих виступів;

4) голоценові - виникли вн слідок винесення дрібнозему під ч с т нення сніжників. уково-пр ктичн цінність групув ння к м'яних розсипів зручн для порівняння різном нітних х р ктеристик досліджув ного об’єкт, їхньої под льшої типології т кл сифік ції, що д сть змогу точніше відтворити п леогеогр фічні умови їхнього утворення т спрогнозув ти їхній под льший розвиток.

1. оворушко . . урумовый морфолитогенез / . . оворушко. - л дивосток :

$$
\text { , 1986. }-210 \mathrm{c} \text {. }
$$

2. $p$ вчук . . лежність суч сних геоморфологічних процесів від типологічних особливостей рельєфу / . . р вчук // існ. ьвів. ун-ту. ип. 13. ер. геогр. - ьвів, 1982. - . 14-18.

3. $р$ вчук . . еоморфологія кибових рп т/ . . р вчук. - ьвів, 2005. -230 с.

4. ру швилли . . леогеогр фический слов рь / . . ру швилли. - оскв , 1986. - 369с. 5. удько . нженерно-геоморфологічний н ліз рп тського регіону кр їни/ . удько, . р вчук. - ьвів, 2002. - 172 с.

6. ливк . . еоморфологія ододільно- ерховинських рп т/ . . ливк.- ьвів, 2001. $152 \mathrm{c}$.

7. $m$ дницький . . о пит ння про плейстоценове зледеніння т походження к м'яних розсипів у орг н х / . . т дницький. - оп. т нові домл. ьвів. ун-ту. 1959. - ип. 8. . 2. - . 10-12.

8. $m$ мn . нглорусский слов рь по физической геогр фи / . т мп. - . : рогрес, 1975. $816 \mathrm{c}$.

9. ушняк. оль процесів гр віт ційної тектоніки у суч сному рельєфотворенні рп т / ушняк, . в ник // роблеми геоморфології і п леогеогр фії кр їнських рп т іприлеглих територій. - ьвів : ид. центр ім. в. р нК , 2006. - . 182-185.

10. Klatka T. Geneza I wiek gołoborzy Lysogorskich. Lodz, 1962. - $125 \mathrm{~s}$.

11. Pękala K. Rymowiska skałne I współczesne procesy morfogenetyczne w Bieszcadach. // Annales universitatis Mariae Curie-Sklodovska. Lublin, Polonia, 1969. vol. XXIV, 2 Sectio B. - 47-98 s.

m ття: н дійшл до редколегї̈ 01.12.2011 прийнят до друку 20.12.2011 


\title{
THE MORPHOLOGY OF STONE FIELDS AT SYVULYANSKY AND DOVBUSHANSKY RIDGES OF SKYBOVI GORGANY
}

\author{
A. Veselova \\ Ivan Franko National University of Lviv, \\ . Doroshenko St., 41, UA - 79000 Lviv, Ukraine
}

The analysis and comparison of the morphology of stone fields by Syvulyanskyi and Dovbushanskyi ridges of Skybovi Gorgany have been made. Morphometric characteristics, mechanism of formation, age and current state have been considered according to their relative distribution on the slopes. Conclusions, based on the paleogeographic conditions of their formation have been made.

Key words: stone fields, slope, roundness, Gorgany, orientation of fragments.

\section{- еселов}

ввовский н цион льный университет имени в н

ул. . орошенко, 41, г. ьвов, 79000, кр ин

ыполнено н лиз и ср внение морфологии к менных россыпей ивулянського и овбуш нского хребтов кибовых орг н. ссмотрено морфометрические х р ктеристики, мех низм обр зов ния, возр ст и современное положение к менных россыпей, относительно их p спростр нения н склон х. дел но выводы относительно п леогеогр фических условий их обр зов ния.

лючевые слов : к менные россыпи, склон, ок т нность, орг ны, ориент ция обломков. 